\title{
The clinical features and prognosis of patients with mucinous breast carcinoma compared with those with infiltrating ductal carcinoma: a population-based study
}

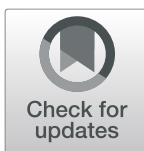

Xingtong Zhou ${ }^{1 \dagger}$, Zhibo Zheng ${ }^{2 \dagger}$, Yan Li ${ }^{1}$, Weiwei Zhao ${ }^{3}$, Yan Lin ${ }^{1}$, Jieshi Zhang ${ }^{2}$ and Qiang Sun ${ }^{1 *}$

\begin{abstract}
Background: At present, the characteristics of mucinous breast carcinoma (MBC) and the factors affecting its prognosis are controversial. We compared the clinical features of $\mathrm{MBC}$ with those of infiltrating ductal carcinoma (IDC) and summarized the relevant prognostic factors.
\end{abstract}

Methods: The Surveillance, Epidemiology, and End Results (SEER) database includes information on 10,593 patients diagnosed with MBC between 2004 and 2016. Chi-square tests and analyses were used to analyze differences in variables between the MBC and IDC groups. Univariate and multivariate Cox proportional hazards models were used to assess the relative impacts of risk factors on cancer-specific survival (CSS) in patients. Kaplan-Meier survival curves were constructed to assess cancer-specific mortality and were compared using the log-rank test.

Results: From 2004 to 2016, 10,593 people were diagnosed with MBC, and 402,797 were diagnosed with IDC. Patients with MBC had significantly higher 5-/10-year CSS rates (96.4\%/93.4\%) than those with IDC (89\%/83.8\%). Compared with IDC patients, MBC patients had less lymph node metastasis, an earlier stage, a higher rate of hormone receptor positivity and a lower expression rate of HER2. Univariate and multivariate analyses showed that age $\geq 60$ years old ( $\mathrm{HR}=1.574,95 \% \mathrm{Cl}: 1.238-2.001, P<0.001)$, singled status ( $\mathrm{HR}=1.676,95 \% \mathrm{Cl}: 1.330-2.112, P<$ 0.001 ) and advanced TNM/SEER stage were independent prognostic risk factors for MBC. In addition, positive estrogen receptor $(H R=0.577,95 \% \mathrm{Cl}: 0.334-0.997, P=0.049)$, positive progesterone receptor $(\mathrm{HR}=0.740,95 \% \mathrm{Cl}$ : $0.552-0.992, P=0.044)$, surgical treatment $(H R=0.395,95 \% \mathrm{Cl}: 0.288-0.542, P<0.001)$ and radiotherapy $(H R=0.589$, 95\%Cl: $0.459-0.756, P<0.001)$ were identified as protective factors.

Conclusion: Compared with IDC, MBC has a better prognosis. For patients with MBC, we identified prognostic factors that can help clinicians better assess patient outcomes and guide individualized treatment.

Keywords: Mucinous breast carcinoma, Surveillance, epidemiology, and end results database, Clinical features, Prognosis

\footnotetext{
*Correspondence: sunqiang_xh@126.com

${ }^{+}$Xingtong Zhou and Zhibo Zheng contributed to the work equally and should be regarded as co-first authors.

${ }^{1}$ Department of Breast Surgery, Peking Union Medical College Hospital,

Chinese Academy of Medical Sciences, No 41 Damucang Hutong, Xicheng District, Beijing 100032, China

Full list of author information is available at the end of the article
}

C C The Author(s). 2021 Open Access This article is licensed under a Creative Commons Attribution 4.0 International License, which permits use, sharing, adaptation, distribution and reproduction in any medium or format, as long as you give appropriate credit to the original author(s) and the source, provide a link to the Creative Commons licence, and indicate if changes were made. The images or other third party material in this article are included in the article's Creative Commons licence, unless indicated otherwise in a credit line to the material. If material is not included in the article's Creative Commons licence and your intended use is not permitted by statutory regulation or exceeds the permitted use, you will need to obtain permission directly from the copyright holder. To view a copy of this licence, visit http://creativecommons.org/licenses/by/4.0/. The Creative Commons Public Domain Dedication waiver (http://creativecommons.org/publicdomain/zero/1.0/) applies to the data made available in this article, unless otherwise stated in a credit line to the data. 


\section{Background}

Breast carcinoma is the most common cancer and leading cause of death among women worldwide. Infiltrating breast carcinoma accounts for the vast majority of all breast cancer types. Infiltrating ductal carcinoma (IDC) is the most common subtype of infiltrating breast cancer, accounting for approximately $70-80 \%$, whereas mucinous breast carcinoma $(\mathrm{MBC})$ is a rare and special subtype.

Currently, $\mathrm{MBC}$ is subdivided into simple mucinous carcinoma and mixed mucinous carcinoma based on whether it contains other types of tumor components. The pathology of simple mucinous carcinoma of the mammary gland is characterized by the cluster-like hyperplasia of tumor cells floating in extracellular mucous fluid, and mucinous cancer components account for more than $90 \%$ of all tumor cells [1]. In addition to mucinous components, mixed mucinous carcinoma also contains in situ ductal carcinoma or other invasive carcinoma components. It is reported that $\mathrm{MBC}$ accounts for $1-6 \%$ of all breast carcinoma and approximately $2.4 \%$ of all infiltrating breast carcinoma [2, 3]. MBC is common among postmenopausal women, and its clinical features are different from those of IDC. High expression of hormone receptors and low expression of human epidermal growth factor receptors (e.g., HER2) were also observed [4-6]. Moreover, the prognosis of MBC patients has been shown to be better than that of IDC patients [6]. The incidence of recurrence or distant metastasis in typical simple MBC patients is low. Most $\mathrm{MBC}$ patients receive postoperative adjuvant endocrine therapy, and fewer patients with MBC need chemotherapy and radiotherapy compared with those with other types of breast cancer [7].

Breast cancer is characterized as a highly heterogeneous tumor, and many clinical features may be prognostic factors for patients. As a rare tumor, $\mathrm{MBC}$ has a good prognosis, but its clinical features and prognostic factors are still controversial. The aim of this study was to compare the pathogenesis, clinical features and prognosis of MBC with those of IDC by a statistical analysis based on the Surveillance, Epidemiology, and End Results (SEER) database. We also evaluated the impact of clinical features on survival in MBC patients, further to identify the prognostic factors associated with cancerspecific survival (CSS).

\section{Methods}

\section{Participants}

The data used in this study were obtained from the SEER database, which is developed by the National Cancer Institute (NCI). The SEER database contains epidemiological characteristics, primary tumor characteristics, progression stages, treatment options and follow-up information of various malignancies, covering approximately $34.6 \%$ of the population in the United States [8]. SEER*Stat 8.3.6 software was used to extract information from the database. We screened information on patients diagnosed with breast cancer January 1, 2004 to December 31, 2016. The pathological diagnosis codes were $8500 / 3$ (IDC) and 8480/3 (MBC). Due to the openness and availability of SEER data, our study was deemed exempt from institutional review board approval.

The exclusion criteria were as follows: 1) patients who lacked major information (e.g., age, tumor pathological type, follow-up information, cause of death); 2) patients with other malignancies found at diagnosis or during the follow-up period (patients with MBC had a higher survival rate than patients with other malignancies; thus, these data would affect CSS if patients with other primary tumors were incorporated into the study). In this study, the following data of MBC and IDC patients were extracted from the SEER database: gender, age, race, marital status, tumor location, grade, stage, estrogen receptor (ER) status, progesterone receptor (PR) status, human epidermal growth factor receptor 2 (HER2) status, treatment history and follow-up information. Additional comparisons of $\mathrm{MBC}$ and IDC patients were also performed.

\section{Statistical analysis}

All statistical analyses were conducted by SPSS 25.0 (SPSS Inc., Chicago, IL, USA) and GraphPad Prism 7 (GraphPad Software). Clinical information and tumor features were summarized with descriptive statistics. Comparisons of categorical variables among different groups were performed by using the Chi square test. Univariate and multivariate Cox proportional hazards models were used to assess the relative impacts of risk factors for CSS in patients. Kaplan-Meier survival curves were constructed to assess cancer-specific mortality, and their comparisons were conducted by using the log-rank test. $P<0.05$ was considered statistically significant.

\section{Results \\ Overview of MBC and IDC patients}

From 2004 to 2016, a total of 10,593 people were diagnosed with $\mathrm{MBC}$, and 402,797 were diagnosed with IDC. The median age of MBC patients was 68 years old (ranged 21-105 years old), and the median follow-up period was 60 months (ranged 1-155 months). The median age of IDC patients was 59 years old (range 15-118 years old), and the median follow-up period was 53 months (ranged 1-155 months). In this study, CSS was defined as endpoint. MBC patients' 5-/10-year CSS rates were $96.4 \% / 93.4 \%$, while IDC patients' 5-/10-year CSS rates were $89 \% / 83.8 \%(P<0.001)$. 
Comparison of baseline characteristics between MBC and IDC patients

The epidemiologic features, clinical features, tumor stage, and pathological features of MBC and IDC patients are summarized in Table 1. In both MBC and IDC patients, men accounted for a very small percentage $(0.4$ and $0.8 \%$, respectively). Besides, the age of women $\geq 60$ years old accounted for $68.0 \%$ of MBC patients and only $48.3 \%$ of IDC patients $(P<0.001)$. In terms of the location of the tumor, it was more common in the upperouter quadrant of the breast, with $50.2 \%$ in MBC and $57.1 \%$ in IDC (Table 1).

\section{Comparison of pathological characteristics between MBC and IDC patients}

Compared with IDC, MBC was characterized by lower lymph node metastasis rate, earlier stage, higher expression rate of ER and $\mathrm{PR}$, and lower expression rate of HER2. In MBC, low-grade tumors accounted for $84.2 \%$ (grade I 52.7\%, grade II 31.5\%), while in IDC, grade I-III accounted for 18.6, 39.5 and $37.3 \%$, respectively. At the time of $\mathrm{MBC}$ diagnosis, $85.5 \%$ of patients were in the N0 stage; while at the time of IDC diagnosis, $63.3 \%$ of patients were in the NO stage. Among the MBC patients, $86.2 \%$ were in the local stage and $10.7 \%$ were in the regional stage; while among the IDC patients, $62.7 \%$ were in the local stage and $31.7 \%$ were in the regional stage. Immunohistochemical analysis of MBC tumors showed that the ER-positive rate was 93.6\%, the PR-positive rate was $84.6 \%$, and the HER2-positive rate was $2.7 \%$; while in IDC tumors, the ER-positive rate was $75.8 \%$, the PRpositive rate was $65.2 \%$, and the HER2-positive rate was $10.1 \%$. In total, $48 \%$ of MBC patients had the Luminal A subtype, and $0.3 \%$ had the basal-like subtype. However, $38.1 \%$ of IDC patients had the Luminal A subtype, and $7.0 \%$ had the basal-like subtype (Table 1 ).

\section{Comparison of treatment between MBC and IDC patients} The vast majority of $\mathrm{MBC}$ and IDC patients underwent surgery (93.9\% with $\mathrm{MBC}$ and $92.8 \%$ with IDC). A total of $47.8 \%$ of $\mathrm{MBC}$ patients received postoperative radiotherapy compared with $51.2 \%$ of IDC patients (Table 1).

\section{Survival analysis of $M B C$ patients}

We also analyzed the risk factors for CSS in MBC patients by using the Cox regression model. Multivariate analysis showed that age $\geq 60$ years old $(H R=1.574$, 95\%CI: $1.238-2.001, P<0.001)$, singled status $(\mathrm{HR}=$ 1.676, 95\%CI: $1.330-2.112, P<0.001)$ and advanced TNM/SEER stage were independent prognostic risk factors for MBC. In addition, positive estrogen receptor (HR $=0.577,95 \% \mathrm{CI}: 0.334-0.997, P=0.049)$, positive progesterone receptor $(\mathrm{HR}=0.740,95 \% \mathrm{CI}$ : 0.552-0.992, $P=0.044)$, surgery $(\mathrm{HR}=0.395,95 \% \mathrm{CI}: 0.288-0.542$,
$P<0.001)$ and radiotherapy (HR $=0.589,95 \% \mathrm{CI}: 0.459$ $0.756, P<0.001)$ were identified as protective factors. There was no significant difference in the status of HER2 receptors $(P>0.05)$ (Table 2$)$. The CSS estimates were classified by age, marital status, $\mathrm{T}$ stage, $\mathrm{N}$ stage, $\mathrm{M}$ stage, ER, PR, surgery and radiotherapy (Fig. 1).

\section{Discussion}

In recent years, the incidence of breast cancer is increasing annually, but the mortality rate is decreasing due to a deeper understanding of breast cancer features and more effective postoperative adjuvant treatment. Breast cancer has a high degree of heterogeneity, and includes different histological types and different molecular subtypes. However, the biological characteristics and clinical outcomes of these subtypes are different [9]. MBC is a special type of invasive breast cancer. Because $M B C$ is rare, there are few studies on this topic, most of which are single-center retrospective studies involving a small sample size of patients. Thus, the purpose of this study was to collect relevant information from the SEER database, and compare the characteristics of $\mathrm{MBC}$ with those of IDC, further to determine the risk factors that affect the prognosis of $\mathrm{MBC}$ patients.

MBC cells generally express high levels of MUC2 and MUC6. MBC cells secrete mucin and produce a large amount of mucin outside the cell. Cancer cells float as a single or small mass in the mucous and are unable to contact the interstitium, thus reducing their invasiveness. Therefore, in general, metastasis does not occur in early stage of $\mathrm{MBC}$, and the prognosis of $\mathrm{MBC}$ has been shown to be better than that of other types of invasive breast cancer $[10,11]$. In this study, more patients with MBC were at a low TNM/SEER stage at the time of diagnosis compared with patients with IDC. Consistent with previous findings, the data from this study also confirmed that patients with $\mathrm{MBC}$ had significantly fewer lymph node metastases and that the 5-/10-year CSS rates were significantly higher compared with those patients with IDC [12-14]. In addition, older postmenopausal women may be more likely to develop $\mathrm{MBC}$. Among the patients included in this study, the median age of IDC and MBC patients was 59 years old and 68 years old respectively, and there was a significant difference.

Compared with IDC, MBC was better reflected in the immunohistochemistry results: ER and PR positivity and HER2 negativity $(P<0.001)$. Regarding the molecular subtype, most MBC patients have the Luminal A subtype, and the other three types were statistically uncommon in MBC patients compared with IDC patients. Most studies have shown that the expression of hormone receptors is significantly higher in $\mathrm{MBC}$ than that in IDC, indicating that $\mathrm{MBC}$ is a strong hormone- 
Table 1 Patients characteristics of MBC patients and IDC patients

\begin{tabular}{|c|c|c|c|}
\hline Characteristics & $\mathrm{MBC} N=10,593(\%)$ & IDC $N=402,797(\%)$ & $P$ \\
\hline Sex & & & $<0.001$ \\
\hline Female & $10,552(99.6)$ & $399,699(99.2)$ & \\
\hline Male & $41(0.4)$ & $3098(0.8)$ & \\
\hline Age & & & $<0.001$ \\
\hline$<60$ years old & $3395(32.0)$ & $208,149(51.7)$ & \\
\hline$\geq 60$ years old & $7198(68.0)$ & $194,648(48.3)$ & \\
\hline Race & & & $<0.001$ \\
\hline White & $8102(76.5)$ & $315,613(78.4)$ & \\
\hline Black & $1177(11.1)$ & $45,881(11.4)$ & \\
\hline Other & $1314(12.4)$ & $41,303(10.3)$ & \\
\hline Marital status & & & $<0.001$ \\
\hline Married & $4993(47.1)$ & $224,449(55.7)$ & \\
\hline Singled & $5054(47.7)$ & $158,735(39.4)$ & \\
\hline Unknown & $546(5.2)$ & $19,613(4.9)$ & \\
\hline Location & & & $<0.001$ \\
\hline Central portion of breast & $847(8.0)$ & $21,247(5.3)$ & \\
\hline Upper-inner quadrant & $1232(11.6)$ & $48,162(12.0)$ & \\
\hline Lower-inner quadrant & $977(9.2)$ & $22,735(5.6)$ & \\
\hline Upper-outer quadrant & $5318(50.2)$ & $229,970(57.1)$ & \\
\hline Lower-outer quadrant & $938(8.9)$ & $29,175(7.2)$ & \\
\hline Unspecific & $1281(12.1)$ & $51,508(12.8)$ & \\
\hline Grade & & & $<0.001$ \\
\hline 1 & $5582(52.7)$ & $74,859(18.6)$ & \\
\hline$\|$ & $3335(31.5)$ & $159,214(39.5)$ & \\
\hline III & $389(3.7)$ & $150,305(37.3)$ & \\
\hline IV & $21(0.2)$ & $2554(0.6)$ & \\
\hline Unspecific & $1266(12.0)$ & $15,865(3.9)$ & \\
\hline SEER stage & & & $<0.001$ \\
\hline Local & $9134(86.2)$ & $252,467(62.7)$ & \\
\hline Regional & $1137(10.7)$ & $127,795(31.7)$ & \\
\hline Distant & $197(1.9)$ & $18,965(4.7)$ & \\
\hline Unspecific & $125(1.2)$ & $3570(0.9)$ & \\
\hline T-stage & & & $<0.001$ \\
\hline $\mathrm{T} 1$ & $6732(63.5)$ & $234,608(58.2)$ & \\
\hline $\mathrm{T} 2$ & $2816(26.6)$ & $119,558(29.7)$ & \\
\hline T3 & $519(4.9)$ & $20,073(5.0)$ & \\
\hline T4 & $207(2.0)$ & $16,860(4.2)$ & \\
\hline Unspecific & $320(3.0)$ & 11,698 (2.9) & \\
\hline N-stage & & & $<0.001$ \\
\hline NO & $9058(85.5)$ & $255,082(63.3)$ & \\
\hline N1 & $822(7.8)$ & $93,750(23.3)$ & \\
\hline N2 & $143(1.3)$ & $22,938(5.7)$ & \\
\hline N3 & $99(0.9)$ & $15,704(3.9)$ & \\
\hline Unspecific & $471(4.4)$ & $15,323(3.8)$ & \\
\hline M-stage & & & $<0.001$ \\
\hline MO & $10,202(96.3)$ & $379,350(94.2)$ & \\
\hline
\end{tabular}


Table 1 Patients characteristics of MBC patients and IDC patients (Continued)

\begin{tabular}{|c|c|c|c|}
\hline Characteristics & $\mathrm{MBC} N=10,593(\%)$ & IDC $N=402,797(\%)$ & $P$ \\
\hline M1 & $183(1.7)$ & $17,192(4.3)$ & \\
\hline Unspecific & $208(2.0)$ & $6255(1.6)$ & \\
\hline TNM stage & & & $<0.001$ \\
\hline । & $6381(60.2)$ & $187,086(46.4)$ & \\
\hline$\|$ & $3183(30.0)$ & 139,311 (34.6) & \\
\hline III & $402(3.8)$ & $45,608(11.3)$ & \\
\hline IV & $183(1.7)$ & $17,195(4.3)$ & \\
\hline Unspecific & $444(4.2)$ & $13,597(3.4)$ & \\
\hline ER & & & $<0.001$ \\
\hline Negative & $187(1.8)$ & $83,543(20.7)$ & \\
\hline Positive & 9915 (93.6) & $305,234(75.8)$ & \\
\hline Unspecific & $491(4.6)$ & $14,020(3.5)$ & \\
\hline$P R$ & & & $<0.001$ \\
\hline Negative & $1036(9.8)$ & $123,454(30.6)$ & \\
\hline Positive & $8958(84.6)$ & $262,619(65.2)$ & \\
\hline Unspecific & $599(5.7)$ & $16,724(4.2)$ & \\
\hline HER2 & & & $<0.001$ \\
\hline Negative & $5124(48.4)$ & $182,050(45.2)$ & \\
\hline Positive & $286(2.7)$ & $40,845(10.1)$ & \\
\hline Unspecific & $5183(48.9)$ & $179,902(44.7)$ & \\
\hline Molecular subtypes & & & $<0.001$ \\
\hline Luminal A & $5088(48.0)$ & $153,463(38.1)$ & \\
\hline Luminal B & $255(2.4)$ & $28,240(7.0)$ & \\
\hline HER2-enriched & $30(0.3)$ & $12,517(3.1)$ & \\
\hline Basal subtypes & $29(0.3)$ & $28,371(7.0)$ & \\
\hline Unspecific & $5191(49.0)$ & $180,206(44.7)$ & \\
\hline Surgery & & & $<0.001$ \\
\hline No & $580(5.5)$ & $25,525(6.3)$ & \\
\hline Yes & 9952 (93.9) & $373,914(92.8)$ & \\
\hline Partial mastectomy & $6713(63.4)$ & $222,175(55.2)$ & \\
\hline Total mastectomy ${ }^{a}$ & $1878(17.7)$ & $75,800(18.8)$ & \\
\hline Radical mastectomy ${ }^{\mathrm{b}}$ & $1334(12.6)$ & $74,648(18.5)$ & \\
\hline Unknown & $27(0.3)$ & $1291(0.3)$ & \\
\hline Unspecific & $61(0.6)$ & $3358(0.8)$ & \\
\hline Radiotherapy & & & $<0.001$ \\
\hline No & $5530(52.2)$ & $196,512(48.8)$ & \\
\hline Yes & $5063(47.8)$ & $206,285(51.2)$ & \\
\hline Survival & & & $<0.001$ \\
\hline 5-year CSS rate & 96.4 & 89.0 & \\
\hline 10-year CSS rate & 93.4 & 83.8 & \\
\hline Early stage 5-year CSS rate & 97.67 & 92.00 & \\
\hline Advanced stage 5-year CSS rate & 38.81 & 27.70 & \\
\hline
\end{tabular}

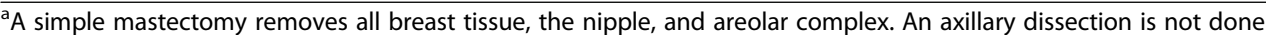

${ }^{\mathrm{b}}$ Radical mastectomy includes modified radical mastectomy, radical mastectomy NOS and extended radical mastectomy 
Table 2 Univariate and multivariate analysis of CSS in MBC patients

\begin{tabular}{|c|c|c|c|c|}
\hline \multirow[t]{2}{*}{ Features } & \multicolumn{2}{|l|}{ Univariate } & \multicolumn{2}{|l|}{ Multivariate } \\
\hline & HR $(95 \% \mathrm{Cl})$ & $P$ value & $\mathrm{HR}(95 \% \mathrm{Cl})$ & $P$ value \\
\hline \multicolumn{5}{|l|}{ Sex } \\
\hline Female & 1 & & - & - \\
\hline Male & $1.834(0.589-5.712)$ & 0.295 & - & - \\
\hline \multicolumn{5}{|l|}{ Age } \\
\hline$<60$ years old & 1 & & 1 & \\
\hline$\geq 60$ years old & $1.570(1.256-1.962)$ & $<0.001$ & $1.596(1.257-2.025)$ & $<0.001$ \\
\hline \multicolumn{5}{|l|}{ Race } \\
\hline White & 1 & & 1 & \\
\hline Black & $1.718(1.325-2.226)$ & $<0.001$ & $1.201(0.918-1.572)$ & 0.181 \\
\hline Other & $0.462(0.302-0.706)$ & $<0.001$ & $0.433(0.281-0.666)$ & $<0.001$ \\
\hline \multicolumn{5}{|l|}{ Marital status } \\
\hline Married & 1 & & 1 & \\
\hline Singled & $2.448(1.964-3.052)$ & $<0.001$ & 1.679 (1.333-2.114) & $<0.001$ \\
\hline \multicolumn{5}{|l|}{ Location } \\
\hline Central portion of breast & 1 & & - & - \\
\hline Upper-inner quadrant & $1.109(0.691-1.781)$ & 0.667 & - & - \\
\hline Lower-inner quadrant & $0.677(0.389-1.178)$ & 0.168 & - & - \\
\hline Upper-outer quadrant & $0.914(0.615-1.358)$ & 0.656 & - & - \\
\hline Lower-outer quadrant & $0.754(0.436-1.304)$ & 0.313 & - & - \\
\hline Unspecific & $3.152(2.108-4.714)$ & $<0.001$ & - & - \\
\hline \multicolumn{5}{|l|}{ Grade } \\
\hline । & 1 & & - & - \\
\hline$\|$ & $1.310(1.031-1.665)$ & 0.027 & - & - \\
\hline III & $2.825(1.931-4.133)$ & $<0.001$ & - & - \\
\hline IV & $2.564(0.635-10.345)$ & 0.186 & - & - \\
\hline \multicolumn{5}{|l|}{ SEER stage } \\
\hline Local & 1 & & - & - \\
\hline Regional & 4.427 (3.453-5.676) & $<0.001$ & - & - \\
\hline Distant & $48.018(37.616-61.296)$ & $<0.001$ & - & - \\
\hline \multicolumn{5}{|l|}{ T-stage } \\
\hline $\mathrm{T} 1$ & 1 & & 1 & \\
\hline $\mathrm{T} 2$ & $2.680(2.070-3.469)$ & $<0.001$ & 1.971 (1.499-2.592) & $<0.001$ \\
\hline T3 & 7.896 (5.726-10.889) & $<0.001$ & $3.321(2.279-4.838)$ & $<0.001$ \\
\hline T4 & $30.059(22.181-40.735)$ & $<0.001$ & $4.382(2.835-6.773)$ & $<0.001$ \\
\hline \multicolumn{5}{|l|}{ N-stage } \\
\hline No & 1 & & 1 & \\
\hline N1 & $3.790(2.881-4.985)$ & $<0.001$ & $1.642(1.194-2.256)$ & 0.002 \\
\hline N2 & 6.135 (3.789-9.932) & $<0.001$ & $2.227(1.316-3.769)$ & 0.003 \\
\hline N3 & $21.156(14.901-30.036)$ & $<0.001$ & 1.678 (1.052-2.674) & 0.030 \\
\hline \multicolumn{5}{|l|}{ M-stage } \\
\hline Mo & 1 & & 1 & \\
\hline M1 & $36.539(28.835-46.302)$ & $<0.001$ & $6.674(4.771-9.336)$ & $<0.001$ \\
\hline
\end{tabular}


Table 2 Univariate and multivariate analysis of CSS in MBC patients (Continued)

\begin{tabular}{|c|c|c|c|c|}
\hline \multirow[t]{2}{*}{ Features } & \multicolumn{2}{|l|}{ Univariate } & \multicolumn{2}{|l|}{ Multivariate } \\
\hline & $\mathrm{HR}(95 \% \mathrm{Cl})$ & $P$ value & $\mathrm{HR}(95 \% \mathrm{Cl})$ & $P$ value \\
\hline 1 & 1 & & - & - \\
\hline$\|$ & $2.967(2.246-3.920)$ & $<0.001$ & - & - \\
\hline III & $10.877(7.662-15.440)$ & $<0.001$ & - & - \\
\hline IV & 75.573 (56.325-101.399) & $<0.001$ & - & - \\
\hline \multicolumn{5}{|l|}{ ER } \\
\hline Negative & 1 & & 1 & \\
\hline Positive & $0.372(0.234-0.591)$ & $<0.001$ & $0.559(0.328-0.953)$ & 0.033 \\
\hline \multicolumn{5}{|l|}{ PR } \\
\hline Negative & 1 & & 1 & \\
\hline Positive & $0.498(0.385-0.645)$ & $<0.001$ & $0.730(0.545-0.97)$ & 0.034 \\
\hline \multicolumn{5}{|l|}{ HER2 } \\
\hline Negative & 1 & & - & - \\
\hline Positive & $0.833(0.339-2.046)$ & 0.691 & - & - \\
\hline \multicolumn{5}{|l|}{ Surgery } \\
\hline No & 1 & & 1 & \\
\hline \multicolumn{5}{|l|}{ Yes } \\
\hline Partial mastectomy & $0.047(0.037-0.061)$ & $<0.001$ & $0.334(0.229-0.488)$ & $<0.001$ \\
\hline Total mastectomy ${ }^{a}$ & $0.095(0.070-0.129)$ & $<0.001$ & $0.435(0.299-0.631)$ & $<0.001$ \\
\hline Radical mastectomy ${ }^{\mathrm{b}}$ & $0.148(0.113-0.195)$ & $<0.001$ & $0.470(0.333-0.665)$ & $<0.001$ \\
\hline \multicolumn{5}{|l|}{ Radiotherapy } \\
\hline No & 1 & & 1 & \\
\hline Yes & $0.316(0.252-0.397)$ & $<0.001$ & $0.668(0.508-0.880)$ & 0.004 \\
\hline
\end{tabular}

${ }^{a}$ A simple mastectomy removes all breast tissue, the nipple, and areolar complex. An axillary dissection is not done

${ }^{\mathrm{b}}$ Radical mastectomy includes modified radical mastectomy, radical mastectomy NOS and extended radical mastectomy

dependent tumor $[15,16]$. The vast majority of MBC patients have the opportunity to receive adjuvant endocrine therapy, thus reducing the risk of local recurrence and distant metastasis after the operation, and the prognosis is significantly better than that of IDC $[17,18]$. In addition, the multivariate survival analysis for MBC patients showed that there were significant differences in positive ER and positive PR, suggesting that the prognosis of $\mathrm{MBC}$ patients with hormone receptor positivity is better than that of MBC patients with hormone receptor negativity. Furthermore, HER2 overexpression is generally believed to be associated with breast cancer recurrence and metastasis. However, this study did not identify HER2 overexpression as an independent risk factor for prognosis in MBC patients $(P=0.083)$ perhaps due to the gradual widespread use of Herceptin therapy in recent years, improving the prognosis of patients with HER2-positive breast cancer.

TNM stage was revealed as an independent risk factor for prognosis in MBC patients. The later the stage is, the worse the prognosis is. Lymph node involvement has always been considered as an important factor affecting the prognosis of $\mathrm{MBC}$ patients $[19,20]$. However, whether tumor size is an independent risk factor remains controversial. Some studies have suggested that $\mathrm{MBC}$ is mainly composed of mucin, but there is no significant relationship between tumor size and prognosis [21]. However, our data showed that $\mathrm{T}$ stage was related to prognosis, and the larger the stage is, the worse the prognosis is. The marital status of the patient also affected the prognosis, we found that a single status was identified as an independent risk factor. Breast cancer patients are overwhelmingly female, and they need emotional support. Married women are more likely to receive psychological support compared with those single women, and mortality of single women was higher than that of married women $[22,23]$.

We found that receiving surgery and postoperative radiotherapy were important protective factors for $\mathrm{MBC}$ patients. Although $\mathrm{MBC}$ has a good prognosis, it still needs to follow the guidelines for surgical treatment and postoperative radiotherapy. Considering the low rate of lymph node metastasis in MBC patients, we believe that sentinel lymph node biopsy should be sufficient in the 


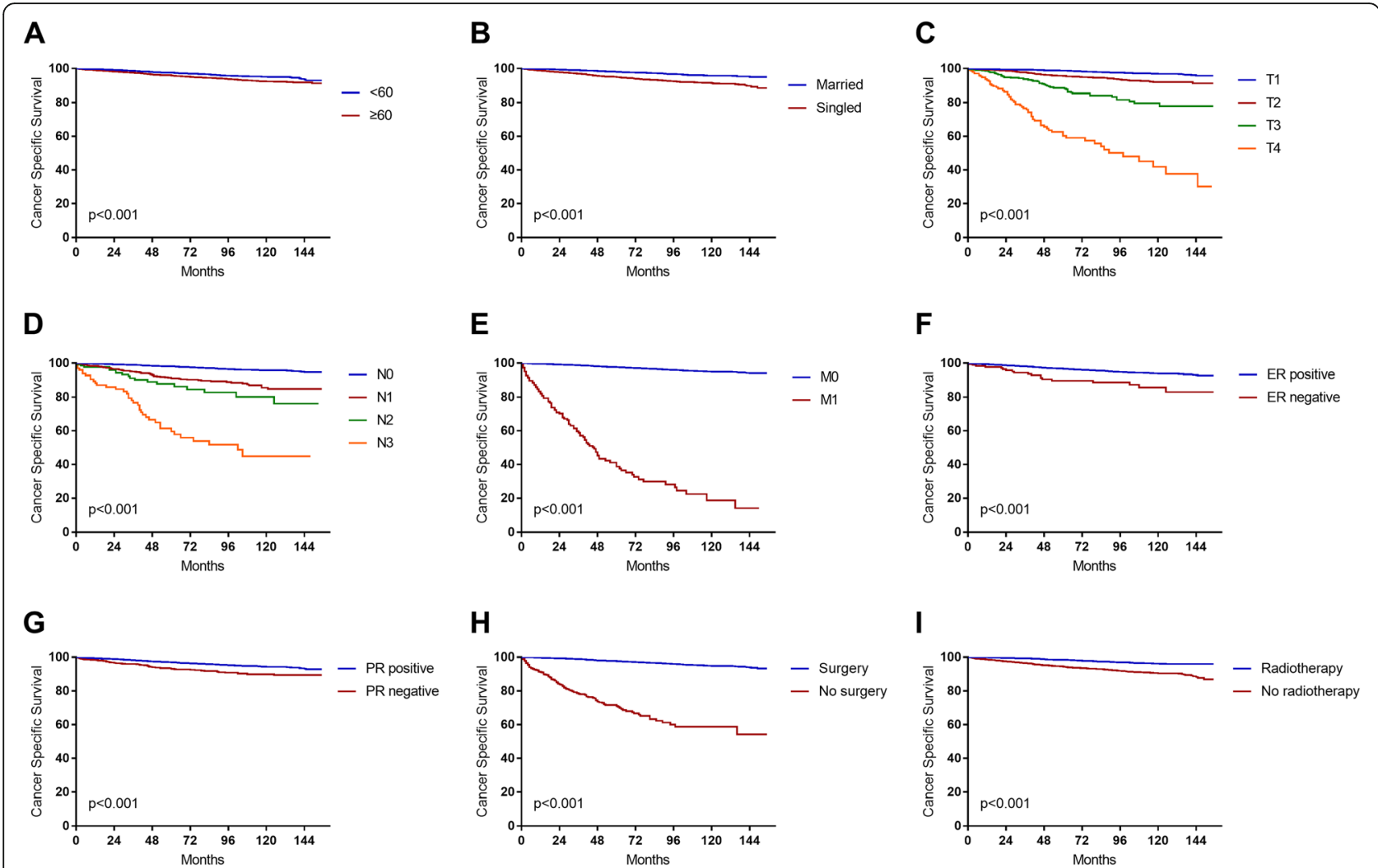

Fig. 1 The cancer-specific survival of patients with MBC associated with different factors. a Age $<60$ and Age $\geq 60 ; \mathbf{b}$ Marital status; c T stage; d N stage; e M stage; f ER; $\mathbf{g}$ PR; $\mathbf{h}$ Surgery; i Radiotherapy

absence of evidence of clinical lymph node metastasis [24]. If the sentinel lymph node is positive, axillary lymph node dissection should be performed again.

There are some limitations in this study. Firstly, for breast tumors, the molecular subtype is an important indicator of prognosis. In the current SEER database, 48.9\% of HER2 information is missing. Secondly, Ki67 and P53 are also related to MBC tumor cell proliferation, recurrence and metastasis, and more research about them should be explored in the future [25, 26]. The SEER database does not yet contain this information. We hope that the SEER database will include more details so we can obtain more accurate research results.

\section{Conclusion}

Compared with IDC, MBC is more likely to occur in older female patients, with an earlier tumor stage, a higher positive rate of hormone receptors, a lower positive rate of HER2 and a better prognosis. For patients with $\mathrm{MBC}$, age $\geq 60$ years old, single status, and late TNM stage are independent prognostic risk factors, while hormone receptor positivity, surgery and radiotherapy are prognostic protection factors. The HER2 status does not affect prognostic outcomes.

\section{Abbreviations}

MBC: Mucinous breast carcinoma; IDC: Infiltrating ductal carcinoma; SEER: The Surveillance, Epidemiology, and End Results; CSS: Cancer-specific survival; NCl: National Cancer Institute; ER: Estrogen receptor;

HER2: Epidermal growth factor receptor 2; PR: Progesterone receptor

\section{Acknowledgements}

None.

Authors' contributions

$X Z$ and $Y L$ contributed to the conception of the study; $Y L$ and $X Z$ contributed significantly to manuscript preparation; Z Z, W Z and J Z performed the data analyses and wrote the manuscript; $Q S$ helped perform the analysis with constructive discussions. The author(s) read and approved the final manuscript.

\section{Funding}

No funding was received for this study.

\section{Availability of data and materials}

The SEER database is supported by the National Cancer Institute (www.seer. cancer.gov) and contains a large amount of information, which provides strong data support for the in-depth study of tumors. Our study also used the data provided by the SEER database to analyze and research the clinical features of breast cancer patients. The datasets generated and analyzed during the current study are available from the corresponding author on reasonable request.

\section{Declarations}

\section{Ethics approval and consent to participate}

This research was approved by the Ethics Committee of Peking Union Medical College Hospital, Chinese Academy of Medical Sciences. All methods were carried out in accordance with relevant guidelines and regulations. 


\section{Consent for publication}

Not applicable.

\section{Competing interests}

The authors of this article have no conflict of interest.

\section{Author details}

'Department of Breast Surgery, Peking Union Medical College Hospital, Chinese Academy of Medical Sciences, No 41 Damucang Hutong, Xicheng District, Beijing 100032, China. ${ }^{2}$ Department of International Medical Services, Peking Union Medical College Hospital, Chinese Academy of Medical Sciences, Beijing, China. ${ }^{3}$ Department of Epidemiology and Biostatistics, School of Public Health, Harbin Medical University, Harbin, China.

Received: 13 November 2020 Accepted: 27 April 2021

Published online: 11 May 2021

\section{References}

1. Vo T, Xing Y, Meric-Bernstam F, Mirza N, Vlastos G, Symmans WF, et al. Long-term outcomes in patients with mucinous, medullary, tubular, and invasive ductal carcinomas after lumpectomy. Am J Surg. 2007;194(4):52731. https://doi.org/10.1016/j.amjsurg.2007.06.012.

2. Bae SY, Choi MY, Cho DH, Lee JE, Nam SJ, Yang JH. Mucinous carcinoma of the breast in comparison with invasive ductal carcinoma: clinicopathologic characteristics and prognosis. J Breast Cancer. 2011;14(4):308-13. https://doi. org/10.4048/jbc.2011.14.4.308.

3. Li Cl, Uribe DJ, Daling JR. Clinical characteristics of different histologic types of breast cancer. Br J Cancer. 2005;93(9):1046-52. https://doi.org/10.1038/sj. bjc.6602787.

4. Rasmussen BB. Human mucinous breast carcinomas and their lymph node metastases. A histological review of 247 cases. Pathol Res Pract. 1985;180(4): 377-82. https://doi.org/10.1016/S0344-0338(85)80110-2

5. Di Saverio S, Gutierrez J, Avisar E. A retrospective review with long term follow up of 11,400 cases of pure mucinous breast carcinoma. Breast Cancer Res Treat. 2008;111(3):541-7. https://doi.org/10.1007/s10549-007-9809-z

6. Li Cl, Moe RE, Daling JR. Risk of mortality by histologic type of breast cancer among women aged 50 to 79 years. Arch Intern Med. 2003:163(18):2149_ 53. https://doi.org/10.1001/archinte.163.18.2149.

7. Diab SG, Clark GM, Osborne CK, Libby A, Allred DC, Elledge RM. Tumor characteristics and clinical outcome of tubular and mucinous breast carcinomas. J Clin Oncol. 1999;17(5):1442-8. https://doi.org/10.1200/JCO.1 999.17.5.1442

8. NCl, Overview of the SEER Program. Available from: http://seer.cancer.gov/a bout/overview.html, 2019.

9. Castaneda CA, Andrés E, Barcena C, Gómez HL, Cortés-Funés H, Ciruelos E. Behaviour of breast cancer molecular subtypes through tumour progression. Clin Transl Oncol. 2012;14(6):481-5. https://doi.org/10.1007/s12 094-012-0827-x

10. Rakha EA, Boyce RWG, Abd el-Rehim D, Kurien T, Green AR, Paish EC, et al. Expression of mucins (MUC1, MUC2, MUC3, MUC4, MUC5AC and MUC6) and their prognostic significance in human breast cancer. Mod Pathol. 2005; 18(10):1295-304. https://doi.org/10.1038/modpathol.3800445.

11. Matsukita S, Nomoto M, Kitajima S, Tanaka S, Goto M, Irimura T, et al. Expression of mucins (MUC1, MUC2, MUC5AC and MUC6) in mucinous carcinoma of the breast: comparison with invasive ductal carcinoma. Histopathology. 2003;42(1):26-36. https://doi.org/10.1046/j.1365-2559.2003. 01530.x

12. Paramo JC, Wilson C, Velarde D, Giraldo J, Poppiti RJ, Mesko TW. Pure mucinous carcinoma of the breast: is axillary staging necessary? Ann Surg Oncol. 2002;9(2):161-4. https://doi.org/10.1007/BF02557368.

13. Park S, Koo J, Kim JH, Yang WI, Park BW, Lee KS. Clinicopathological characteristics of mucinous carcinoma of the breast in Korea: comparison with invasive ductal carcinoma-not otherwise specified. J Korean Med Sci. 2010:25(3):361-8. https://doi.org/10.3346/jkms.2010.25.3.361.

14. Kashiwagi S, Onoda N, Asano Y, Noda S, Kawajiri H, Takashima T, et al. Clinical significance of the sub-classification of 71 cases mucinous breast carcinoma. Springerplus. 2013;2(1):481. https://doi.org/10.1186/2193-1 801-2-481.

15. Peng PL, Zhao DC, Zhou YD, Mao F, Zhao JL, Sun Q. Expressions of Estrogen Receptor,Progestogen Receptor,Cerb-B2,and Ki67 Index in the Simple Mucinous Carcinoma of the Breast. Zhongguo Yi Xue Ke Xue Yuan
Xue Bao. 2015;37(6):720-3. https://doi.org/10.3881/j.issn.1000-503X.2015.06 014.

16. Hsu YH, Shaw CK. Expression of p53, DCC, and HER-2/neu in mucinous carcinoma of the breast. Kaohsiung J Med Sci. 2005;21(5):197-202. https:// doi.org/10.1016/S1607-551X(09)70188-3.

17. Zhang M, Teng XD, Guo XX, Zhao JS, Li ZG. Clinicopathological characteristics and prognosis of mucinous breast carcinoma. J Cancer Res Clin Oncol. 2014;140(2):265-9. https://doi.org/10.1007/s00432-013-1559-1.

18. Cao AY, He M, Liu ZB, di GH, Wu J, Lu JS, et al. Outcome of pure mucinous breast carcinoma compared to infiltrating ductal carcinoma: a populationbased study from China. Ann Surg Oncol. 2012;19(9):3019-27. https://doi. org/10.1245/s10434-012-2322-6.

19. Skotnicki P, Sas-Korczynska B, Strzepek L, Jakubowicz J, Blecharz P, Reinfuss $M$, et al. Pure and mixed mucinous carcinoma of the breast: a comparison of clinical outcomes and treatment results. Breast J. 2016:22(5):529-34. https://doi.org/10.1111/tbj.12621

20. Komenaka IK, el-Tamer MB, Troxel A, Hamele-Bena D, Joseph KA, Horowitz E, et al. Pure mucinous carcinoma of the breast. Am J Surg. 2004;187(4): 528-32. https://doi.org/10.1016/j.amjsurg.2003.12.039.

21. Peng $L$, Sun $Q$, Liang $Z Y$, Zhou YD, Mao F, Guan JH. Pure mucinous carcinoma of the breast: a clinicopathologic analysis with 56 patients. Chin Med Sci J. 2010;25(2):115-8. https://doi.org/10.1016/S1001-9294(10)60033-8.

22. Hinyard L, Wirth LS, Clancy JM, Schwartz T. The effect of marital status on breast cancer-related outcomes in women under 65: a SEER database analysis. Breast. 2017;32:13-7. https://doi.org/10.1016/j.breast.2016.12.008.

23. Martinez ME, et al. Prognostic significance of marital status in breast cancer survival: a population-based study. PLoS One. 2017;12(5):e0175515. https:// doi.org/10.1371/journal.pone.0175515.

24. Ranade A, Batra R, Sandhu G, Chitale RA, Balderacchi J. Clinicopathological evaluation of 100 cases of mucinous carcinoma of breast with emphasis on axillary staging and special reference to a micropapillary pattern. J Clin Pathol. 2010;63(12):1043-7. https://doi.org/10.1136/jcp.2010.082495.

25. Pan B, Yao R, Shi J, Xu QQ, Zhou YD, Mao F, et al. Prognosis of subtypes of the mucinous breast carcinoma in Chinese women: a population-based study of 32-year experience (1983-2014). Oncotarget. 2016;7(25):38864-75. https://doi.org/10.18632/oncotarget.8778.

26. Lei L, Yu X, Chen B, Chen Z, Wang X. Clinicopathological characteristics of mucinous breast Cancer: a retrospective analysis of a 10-year study. PLoS One. 2016;11(5):e0155132. https://doi.org/10.1371/journal.pone.0155132.

\section{Publisher's Note}

Springer Nature remains neutral with regard to jurisdictional claims in published maps and institutional affiliations.

Ready to submit your research? Choose BMC and benefit from:

- fast, convenient online submission

- thorough peer review by experienced researchers in your field

- rapid publication on acceptance

- support for research data, including large and complex data types

- gold Open Access which fosters wider collaboration and increased citations

- maximum visibility for your research: over $100 \mathrm{M}$ website views per year

At BMC, research is always in progress.

Learn more biomedcentral.com/submissions 